\title{
Digitalization as a Determinant of Tax Revenues in OECD Countries: A Static and Dynamic Panel Data Analysis
}

\begin{abstract}
By David Hanrahan*
The tax challenges of digitalization have been to the forefront of national and international discussions on public revenues in recent years. The digital transformation is seen as being an exacerbating factor in the erosion of tax bases and the shifting of profits to low tax jurisdictions, particularly by multinational companies, thus reducing tax revenues for governments. While there is a large literature examining the role of ICT and digitalization in raising economic growth, productivity and other macroeconomic variables, the relationship between digitalization and tax revenues has been relatively understudied - despite being one of key drivers of what could be most significant change to international tax rules in a century. This study utilizes panel data covering OECD countries during the period from 1995 to 2018, and examines the effect of the rise of digitalization on tax revenues employing both static and dynamic panel data analysis techniques. The findings indicate that digitalization may have a negative impact on the ability of a country with high digital dynamics to generate higher tax returns.
\end{abstract}

JEL Codes: H20, H25, L81, L86

Keywords: digitalization, taxation, tax revenues, ICT, OECD countries

\section{Introduction}

Background

The tax challenges of digitalization have been the focus of much research by academics and policymakers at both national and international levels in recent years (OECD 2017). This has been particularly true since the Global Financial Crisis of 2007/08, when the public finances of many countries were strained in the face of rising debt and substantial deficits. Governments came under intense pressure from voters facing years of austerity and restrictive fiscal policy, i.e., rising taxes and falling government spending, leading many people to become disillusioned with globalization and to protest at what they perceived to be "unfair" taxation (this pressure also intensified over the decade from 2008-2018 as a result of reports based on numerous financial scandals including the leaking of documents concerning tax evasion and corruption such as the so-called Swiss leaks, LuxLeaks and Panama Papers). Thus, the issue of the erosion of national tax bases and the shifting of profit from high-tax to low-tax jurisdictions has been high on the policy agenda for some time. While digital firms are not exclusively responsible for base erosion and profit shifting (BEPS), it is argued that the process of digitalization

${ }^{*} \mathrm{PhD}$ Researcher, EIIW/University of Wuppertal, Germany. 
exacerbates these issues (OECD 2014, p. 13), reducing the base available for national governments on which to levy taxes.

Digitalization has significantly and irrevocably changed all economies across the globe over the last three decades in particular. The process of digitalization, the challenges and, to a much lesser extent, the opportunities it represents to economies have been hotly debated. The diffusion of the Internet, and information communication technologies (ICT) more generally, have been well documented in the literature. However, it has also long been argued that digitalization has a negative impact on the tax raising capabilities of national governments dealing with a new, digital world "without borders". One early warning on the negative impact of Internet-based activities with regard to tax revenues came from Tanzi (1996). Tanzi identified various technological developments - namely aspects of digitalization such as e-commerce, electronic money and cross-border transactions - as being a form of "fiscal termite" which would ultimately erode and undermine the foundations of national tax systems and likely lead to a discernible fall in the ratio of tax revenue to GDP in many OECD countries (Tanzi 2000, p. 15). However, the question must be asked: Is there a "Tanzi paradox" to paraphrase the well-known Solow paradox - can the transformative process of digitalization be seen everywhere, except in the tax revenue statistics?

However, despite the recent focus on the tax challenges of digitalization by policymakers and in academia in recent years, digitalization has been little studied in the literature as a determinant of taxation with a lack of solid, data-based evidence for the flaws which have been asserted to exist in the current international tax system (Olbert and Spengel 2019).

This paper investigates the relationship between digitalization and tax revenues in OECD countries (covering all 36 OECD member countries as of 2019) as a contribution towards filling this gap. As a group of developed and advanced economies, the OECD has consistently been to the forefront of attempting to find a consensus-based, multilateral solution to the issues raised by BEPS and the tax challenges of digitalization since being tasked with this role by major global economies. Representing some of the most advanced (in broader terms) and most digitalized economies globally, the OECD is the natural starting point to examining this issue - with 8 of the top 10 countries for e-commerce sales globally being OECD members (UNCTAD 2019) and Internet intensity reaching saturation levels in many countries.

Understanding the role of digitalization in terms of tax revenues is a crucial issue to consider as the OECD attempts to reach a solution in late 2020 as intended. The importance of digitalization during the coronavirus crisis in 2020 (with millions of people worldwide working remotely, or engaged in e-learning and other online solutions) will again bring the challenges it presents to governments to the fore as states seek to recover from the deficits and rising national debt incurred during that crisis.

Using panel data over the period from 1995-2018, including a novel proxy for digitalization, the impact of advancing digitalization over time is examined in order to test Tanzi's "fiscal termite hypothesis" on the basis of the available macroeconomic data on tax revenue. 


\section{Digitalization}

While an in-depth discussion of digitalization ${ }^{1}$ is beyond the scope of the present paper, it is worth making some observations on the dynamics of the process (for a broader discussion on digitalization see, e.g., Corrocher and Ordanini 2002). The OECD describes the digital economy as the result of "a transformative process brought about by information and communication technology (ICT)" (OECD 2013a, p. 11). Many forms of ICT have become general purpose technologies impacting and reshaping both economies and societies (OECD 2013b). This process is also known as digitalization.

As Internet intensity rose from the mid-1990s (see Figure 1), traditional firms increasingly moved from a traditional "bricks and mortar" to a "clicks and mortar" business strategy, combining traditional stores and outlets with an online presence, and many new firms (based entirely online) emerged (e.g., Amazon (founded 1994), Yahoo and eBay (founded 1995), Google (founded 1998)). Fast-paced technological progress and falling real prices of ICT (Welfens and Perret 2014) allowed ICTs to become ubiquitous within a very short period of time. Figure 1 shows how average Internet use grew in OECD countries particularly from 1994 on - displaying a familiar S-shaped curve for the diffusion of innovations (Rogers 2003). It is estimated that global e-commerce sales reached over $\$ 29$ trillion in 2017 with 1.3 billion people engaging in e-commerce transactions, with growth in cross-border transactions (particularly likely to create taxing issues) outpacing growth in e-commerce over all in recent years - cross-border shoppers represented $15 \%$ of global online shoppers in 2015, but 21\% in 2017 (UNCTAD 2019, see also OECD 2019c).

Digitalization is also a phenomenon which will continue to challenge governments and tax authorities into the future, with the so-called Fourth Industrial Revolution - involving developments such as big data, artificial intelligence, robotics, 3D printing and the Internet of Things - likely to mean that the challenges posed by digitalization to tax revenues shall continue if not even worsen over time.

\footnotetext{
${ }^{1}$ Note, that while some researchers have identified different phases of the transformative process (e.g., Verhoef et al. 2019), for the purposes of the present paper, it is assumed that digitalization has been a continuous, singular process.
} 
Figure 1. Individuals using the Internet as Percentage of the Population, OECD Average, 1990-2017

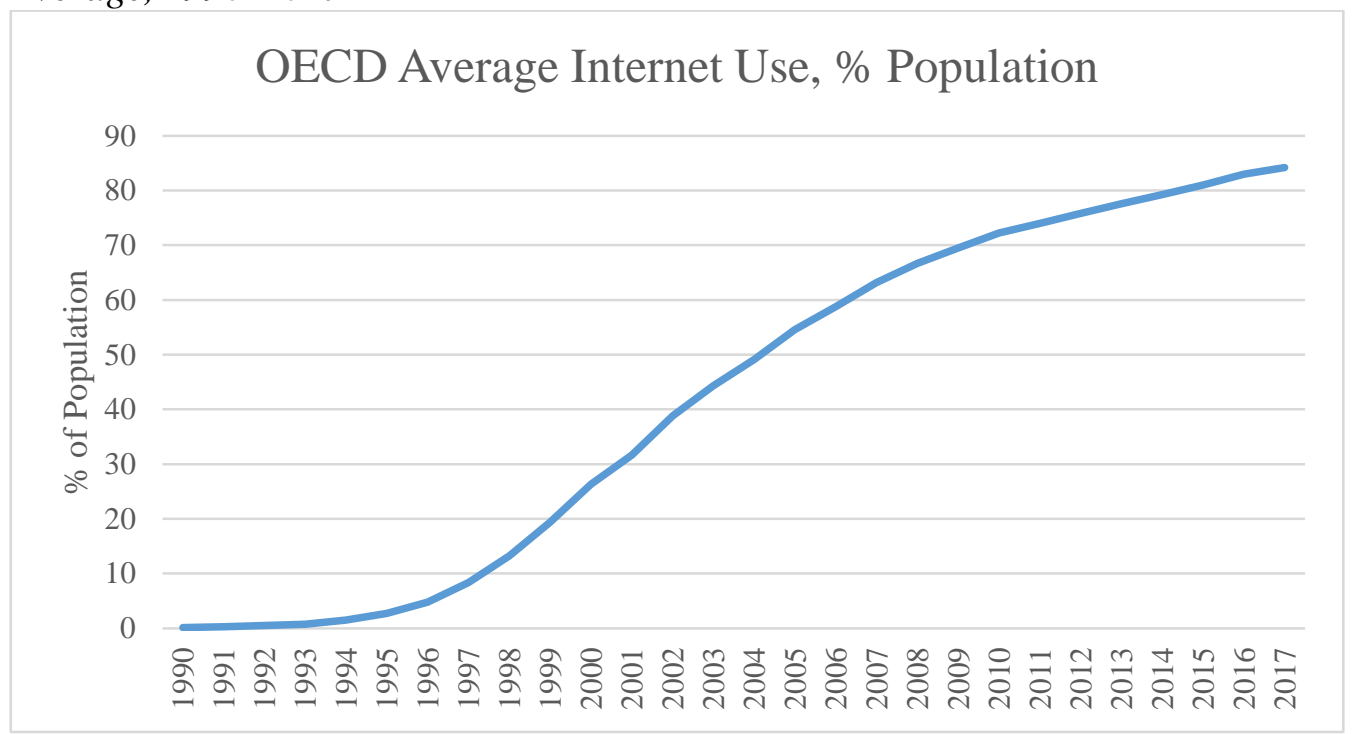

Source: Own representation of data from World Bank.

From Figure 1, one can see that average Internet use in OECD countries was relatively stable in the early 1990s, before Internet usage rates rose steadily from circa 1996 until the late 2000s as saturation intensities began to be reached in some countries, for example 98\% usage in 2017 in Iceland, with Italy, Mexico and Turkey at the bottom of the OECD rankings with $63 \%, 64 \%$ and $65 \%$, respectively.

\section{The Tax Challenges of Digitalization}

Within a few years of significant growth in terms of Internet usage in the early to mid-1990s, the role of ICT and e-commerce in particular came on the national and international policy agenda, with the OECD's 1998 Ottawa Ministerial Conference being the first international ministerial-level conference to deal with the issue of e-commerce (Wyckoff and Loux 2019). However, in a survey of national responses to the challenge of taxing e-commerce in 2006, Cockfield (2006) shows that over the ten years from the mid-1990s to the mid-2000s, many countries had not enacted any significant legislation with regard to taxing the digitalizing economy. The result of this seeming inaction was that the digitalization of modern economies had "disturbed and outmanoeuvred taxes" (Corkery et al. 2013, p.1).

The effect of this lack of action - possibly due to a quasi "infant industry" motivation - was that the productivity gains associated with digitalization did not result in increased tax revenues, particularly for larger countries which have been "sorely tested" by the process (Collin and Colin 2013, p. 5). The tax challenges of digitalization are primarily related to corporate tax revenues and sales/value-added taxes on cross-border consumption with digital firms having the ability to take advantage of differentials in tax rates. Aspects of the new digitalized economies, which pose significant threats to the tax base and revenue collection of countries, 
include, but are not limited to corporation tax issues surrounding mobility (of firms, users, assets), the use of data and intangibles in particular, network effects, platform models and cross-border transactions (for a broader discussion of specifics of the tax challenges of digitalization, see e.g., OECD 2015, 2018, 2019b, SandZantman 2018, Köthenbürger 2020). Meanwhile, digitalization also poses threats to the generation of value-added taxes as the share of e-commerce in overall retail sales continue to grow, in particular cross-border transactions which are difficult and costly to police by tax authorities. The rise of digitalization and the ease of modern communication also facilitate high income individuals relocating from high tax to lower tax jurisdictions also undermining personal income tax revenues.

In the aftermath of the Global Financial Crisis and with the onset of the sovereign debt crisis in certain countries in Europe, the issue of fair taxation of multinationals began to come to the fore, with a new impetus being provided by the leaders of the G20 at the Los Cabos Summit, in Mexico, in 2012 and of the G8 at Lough Erne in 2013 as they stressed the need for governments to act in order to prevent base erosion and profit shifting (G20 2012, G8 2013) and from the OECD itself which had proposed work on the area of BEPS to the G20 prior to the Los Cabos summit. At the same time, expert working groups were commissioned to examine the issue of taxation and the digital economy at an international level (European Commission 2014, ITU 2015).

Having received the political backing and financial support to proceed with an examination of issues surrounding BEPS, the OECD published an Action Plan, which detailed 15 areas which required particular attention, in 2013 (OECD 2013a). The first of these areas, i.e., the OECD's Action Plan 1, tackled the tax challenges of the digital economy (OECD 2014, 2015). With no consensus solution being found by the OECD in 2015, individual states took it upon themselves to proceed on a unilateral basis and enact various taxes and tax-related measures in order to try to generate additional tax revenue from digital firms. These measures generally take the form of turnover taxes, withholding taxes, alternative thresholds for the purposes of a permanent establishment (and thus a taxable presence) and specific measures targeting multinational firms, with measures being announced or enacted in, amongst others, the United Kingdom, France, Italy, Spain, Hungary, Turkey and Israel (for discussion of selected unilateral measures, see UN 2017, Hadzhieva 2019, Agyropolou 2019) as well as proposals for a Digital Services Tax at an EU level from the European Commission (European Commission 2017, 2018). Having received a new mandate, work continues at OECD level to develop an international solution to the tax challenges of digitalization (OECD 2018, 2019a). In October 2020, the OECD released the blueprints of its new "two-pillar" proposed approach to fairer international taxation for public consultation. The OECD proposals include measures designed to ensure more transparent and equitable taxation of large multinational firms include leading digital companies and digitalized economies (OECD 2020b).

However, while many seem to accept that digitalization self-evidently poses a challenge to the tax generating capabilities of national governments, there are also analyses that question the notion that digitalization and digital firms pose a particular and pressing challenge in terms of tax (Lee-Makiyama and Verschelde 
2016, Schoen 2018). In support of its own move towards an EU tax on digital services, the European Commission has argued that international digital firms faced an average effective corporate tax rate in the EU28 of just 9.5\%, compared to the $23.3 \%$ effective corporate tax rate faced by "traditional" international firms (European Commission 2017). These figures have been called into question by, amongst others, Bauer (2018), who notes that the figures used by the Commission do not even appear in the sources cited by the Commission in support of their claim and it is unclear how the Commission arrived at their suggested respective corporate tax rates. Bauer (2019) and Lee-Makiyama and Verschelde (2016) have argued that real-world data shows that digital firms indeed face effective corporate tax rates similar to more traditional, less digital firms (e.g., automobile manufacturers). Furthermore, recent studies of the tax planning of some firms reveal findings which seem difficult to reconcile with claims that digital firms face as more traditional firms, for example the case of Apple, with effective tax rates of key Apple subsidiaries of less than a tenth of one percent (Ting and Gray 2019).

On the other hand, it is also broadly acknowledged that digitalization could also have a positive effect on tax revenues through direct and indirect channels. On the one hand, digitalization improves the performance of tax authorities through better software, online tax return filing, and better record keeping etc. improving both compliance on the part of taxpayers and more efficient tax collection (IMF 2018). Digitalization can also be seen as a crucial driver of innovation and growth (Olbert and Spengel 2017). This role can indirectly improve revenue- raising capabilities of government. Digitalization is associated with economic growth, productivity, inward foreign direct investment, and international trade as will be explored in the subsequent literature review.

Figure 2. Average Tax Revenues OECD Countries as Percentage of GDP, 1990 2018

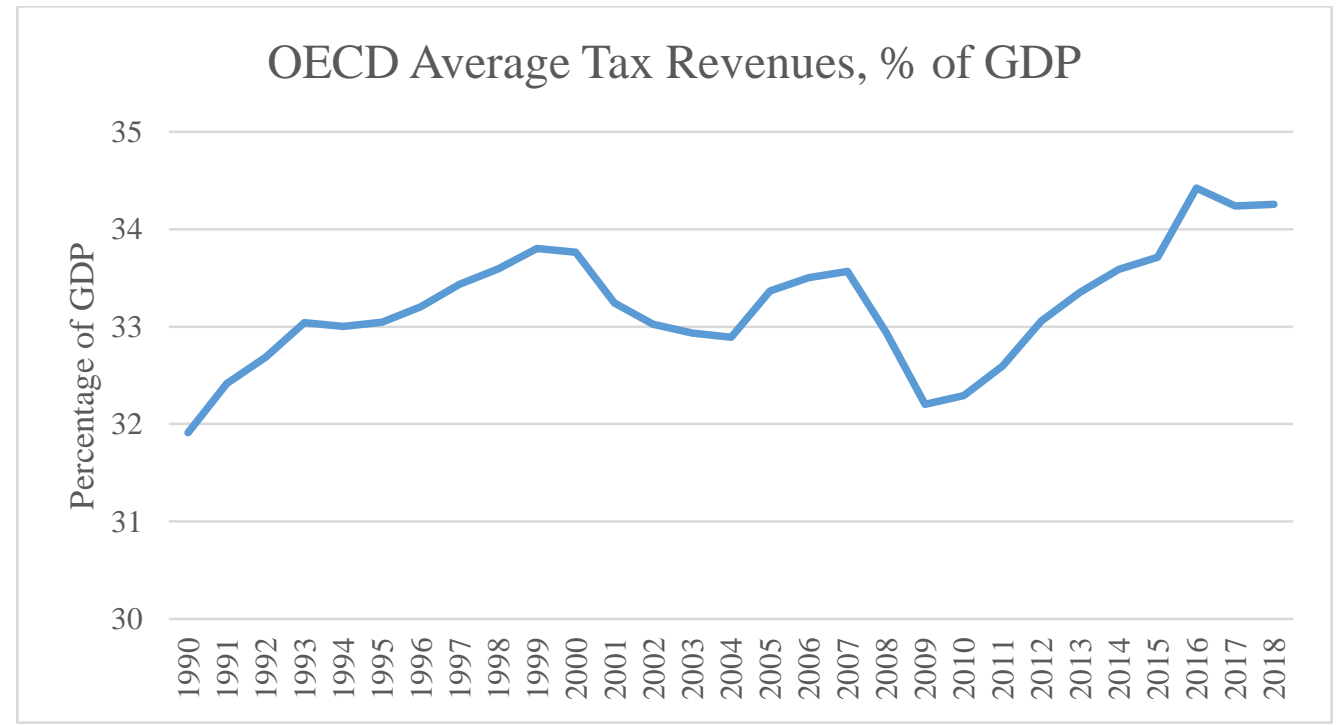

Source: Own representation based on data available from the OECD.

A brief look at average OECD tax revenues over the time period from the beginnings of the process of digitalization in 1990 to 2018, shows no prima facie 
evidence of tax revenues being undermined by fiscal termites, rather average tax revenues as a percentage of GDP in the OECD have risen by circa two percentage points over the same time period (with two noticeable periods of decline, namely the aftermath of the "dot-com" bubble and September $11^{\text {th }}$ attacks in 2000/01, and the Global Financial Crisis from 2007/08).

Thus, the following questions can be asked: Does digitalization really undermine tax revenues? What role does digitalization play as a determinant of tax revenues in some of the most digitalized economies? This paper makes two main contributions to the literature. Firstly, by examining a relatively homogeneous grouping in terms of tax and digitalization in the OECD countries, who are also to the forefront of the search for an international solution to the challenges posed by digitalization, it avoids possible misleading conclusions which would be drawn from an analysis of more heterogeneous countries who are more disparate in terms of economic development, digitalization and tax capacity. The marginal effect of digitalization on tax revenues can be expected to be different for less developed countries with lower tax capacity than for more developed economies. Secondly, this paper employs a novel proxy of digitalization in IP allocation data which allows a broader measure of digitalization than more traditional measures used in the literature such as Internet usage statistics.

The rest of the paper is structured as follows: The subsequent section presents an overview of the literature on the determinants of tax revenue from a macroeconomic perspective. This is followed by a presentation of the data and methodology used in the present analysis and subsequently the empirical models used in the analysis. Following that, the results of the empirical analysis are presented and discussed. The paper concludes with a view on the policy options and ideas for future research.

\section{Literature Review}

The body of literature examining the determinants of tax revenues is broad. Many contributions have sought to examine the principal determinants of tax revenue and certain key determinants shall be presented here as some of these determining factors will be included in the subsequent empirical analysis.

Eltony (2002), looking at panel data covering a selection of 16 Arab countries, finds inter alia that the level of economic development is a strong determinant of tax revenue mobilization. Gupta (2007), using panel data to examine over 100 developing countries over a period of 25 years, has provided further supportive evidence for earlier findings that economic development in terms of GDP per capita is a strong determinant of tax revenue, as is trade openness. Furthermore, the sectoral composition of economies is related to tax revenue generation - in particular, the share of agriculture is negatively related to tax revenue. Stotsky and Woldemariam (1997), who use panel data covering over 40 sub-Saharan African countries during the period from 1990-1995, show that the share of agriculture in GDP is significantly negatively related to tax share as are import and export shares (i.e., openness). Karagöz (2013) - looking at Turkey - 
finds that the share of industry is positively related to tax revenues. Other contributions to the literature consider the level of public debt (Teera and Hudson 2004) and socio-economic and institutional factors such as the level of political rights, civil liberties (Bird et al. 2008) and education (Piancastelli 2001). More recently, Angeles-Castro and Ramirez-Camarillo (2014) providing further support for the findings of the previous researchers using a panel dataset covering OECD countries during the period from 2001 to 2011.

Many studies have also examined the macroeconomic effects of digitalization - usually employing a proxy indicator such as Internet usage intensity. Productivity gains related to Internet usage and diffusion have been identified in macroeconomic data (Oliner and Sichel 2000, Jorgenson 2001, Collechia and Schreyer 2002). At the same time, the Internet has been found to have a significant and positive impact on economic growth (Noh and Yoo 2008, Salahuddin and Alam 2016). Other contributions have considered the impact of the Internet on international trade (Xing 2018, Meijers 2014, Vemuri and Siddiqi 2009, Baunsgaard and Keen 2010), foreign direct investment inflows (Choi 2003) and inflation (Yi and Choi 2005, Csonto et al. 2019 - who use the same data on IPv4 and IPv6 address allocations as the present study to construct a digitalization index in order to examine the impact of digitalization on inflation). Looking at ICT and income inequality, Richmond and Triplett (2018) examine panel data covering 109 countries over the period 2001-2014 and find that the impact of ICT on income inequality varies by type of the type of ICT considered, whereby increases in fixed broadband subscriptions are associated on average with increases in income inequality, while increases in mobile phone subscriptions are associated on average with decreases in income inequality, with the former effect larger than the latter. Jaumotte et al. (2008) also find that income inequality in many countries has increased due to the biased nature of digitalization which raises the relative demand for, and thus wage premium of, skilled workers who possess the human capital required to fully exploit the benefits of these technological developments (on inequality issues, see also Allen, 2017).

Combining these two strands of the literature on the determinants of tax revenue and digitalization using macroeconomic data is a newly emerging field for research ${ }^{2}$. Those studies which have looked at this issue have considered large samples of developed and developing countries, the highly digitalized with the less digitalized (where the marginal effects of increasing digitalizing on e.g., growth and tax revenues may be larger) and high tax countries with countries with lower overall tax burdens. Koyuncu et al. (2016) explore the impact of ICT penetration on tax revenues. Looking at 157 countries and four indicators of ICT penetration, the authors find that ICT penetration does increase tax revenue across countries

\footnotetext{
${ }^{2}$ Some contributions have used microeconomic data to study the relationship between ICTs and tax revenues. Looking at the online purchase decisions of 25,000 US consumers, Goolsbee (2000) could show that consumers living in high sales tax jurisdictions were significantly more likely to buy items online, suggesting that early Internet adopters were already motivated to avoid sales tax thus reducing the tax base and, ultimately, tax revenues. Bruce and Fox (2000) also find that ecommerce was reducing the sales tax base in the US, estimating over $\$ 10$ billion in tax revenue losses in 2003. Many studies have shown similar results in relation to sales and value-added taxes.
} 
during the period 1990 to 2013. Gnangnon and Brun (2018) consider their work to be the first study to investigate the linkage between a variable that they calculate as representing each country's "Internet gap" (i.e., the ratio of a country's internet usage intensity to the world average internet usage intensity) and public revenue mobilization in a sample of 164 countries for the period from 1995 to 2013. Their analysis suggests that by reducing the Internet gap, countries can raise their public revenues with low-income countries standing to benefit the most. Meanwhile, Gnangnon and Brun (2019) analyze the impact of the Internet on resource versus non-resource revenue for 99 countries over the period 1995-2015, finding that a higher Internet usage intensity has a negative effect on resource revenue and a positive effect on non-resource revenue (with the impact of the Internet being higher for less developed countries). The OECD, as a more homogenous group in terms of economic development, digitalization and the tax burden, while also being to the fore in examining the issue of the tax challenges of digitalization, is an interesting sub-group for the subsequent analysis.

\section{Methodology}

\section{Measuring Digitalization}

The impact of digitalization on tax revenues is examined using a model where the explanatory variables are standard in the existing literature on the determinants of tax revenue with the exception of the variable of interest - a singular measure of digitalization. In the literature, a number of variables have been found to be significant determinants of public revenues as discussed in the literature review, namely the level of economic development, sectoral composition, international openness, as well as socio-economic factors including life expectancy, health, education and political and civil rights of residents.

Trying to measure digitalization has proved a difficult task. While many individual indicators exist, it is rarely possible to get a complete picture without combining several indicators. Many attempts have been made, primarily by international organizations, to measure digitalization to allow cross-country comparison. First published in 1997, a pioneering attempt was made by the International Data Corporation and its Information Society Index covering 53 countries. Since then, a number of broadly similar indices have been published by the World Economic Forum (Networked Readiness Index from 2002, Knowledge Economy Index from 2005), the International Telecommunications Union (ICT Development Index from 2002, Digital Access Index from 2003, Digital Opportunity Index (now known as the ICT Development Index) and the ICT Opportunity Index from 2005), the United Nations (Technology Achievement Index from 2001, E-Government Development Index from 2002, ICT Diffusion Index from 2006) and the EU (Digital Economy and Society Index from 2014) with a variety of countries, indicators and sub-indicators and time periods covered (for more, see Kononova 2015). 
Meanwhile, Corrocher and Ordanini (2002) created a synthetic index and used their index to determine a "digital divide" by means of the standard deviation of each country's result from the mean. More recently, some researchers have compiled digitalization indices for their own research. Katz et al. (2014) construct an index comprised of six components (affordability, infrastructure reliability, network access, capacity, usage and human capital) and 24 sub-indicators. Camara and Tuesta (2017) have created the DiGiX, a digitization index, with six principle dimensions (infrastructure, households' adoption, enterprises' adoption, costs, regulation and contents) and 21 sub-indicators, for 100 countries in 2016 with a ranking for that year based on data for 2015 .

The varying nature of individual indices from year to year (where new indicators have been added, other indicators dropped etc. - consider the rise of mobile internet and the role of apps in recent years which are not reflected in earlier years), or the relatively small number of sample years available means that such synthetic indices are not conducive to be used for an analysis over a longer time period.

This paper adapts the proxy used in Csonto et al. (2019) - i.e., the number of internet protocol (IP) addresses allocated per country as a measure of digitalization. An IP address is a numerical label or identification key which is assigned to every device connected to a computer network communicating using internet protocol i.e., every device connected to the internet including desktop computers, laptops, tablets, smartphones and networked devices such as printers, scanners etc.

With the exponential growth of Internet usage and the progress of digitalization, the number of devices connected to the Internet and thus the demand for the number of IP addresses has also grown exponentially. In use since the 1980 s, IPv4 allows for $2^{32}$ IP addresses. Meanwhile, with a view to the growing demand, IPv6 was introduced in 2012 as a parallel network and allows for $2^{128} \mathrm{IP}$ addresses, thus ensuring a supply of addresses to meet growing demand, as internet diffusion continues and the Internet of Things continues to see more and more devices connected to the internet, from household appliances to cars. Since its introduction, the allocation of IPv6 addresses has also grown dramatically (see Figure 3; a table with all OECD countries ranked according to their IP address allocations for 2018 can be found in the appendix, Table 5) with IP addresses being allocated by the Regional Internet Registry to service providers or private or public entities. Following the introduction of iOS and Android operations systems in 2007 and 2008, respectively, the rapid diffusion of smartphones globally over the following years can be seen in the striking growth in IP address allocations (on smartphone diffusion, see Cho (2015) and Gündüc (2019)). 
Figure 3. Average Number of IP Addresses Allocated per Capita in the OECD

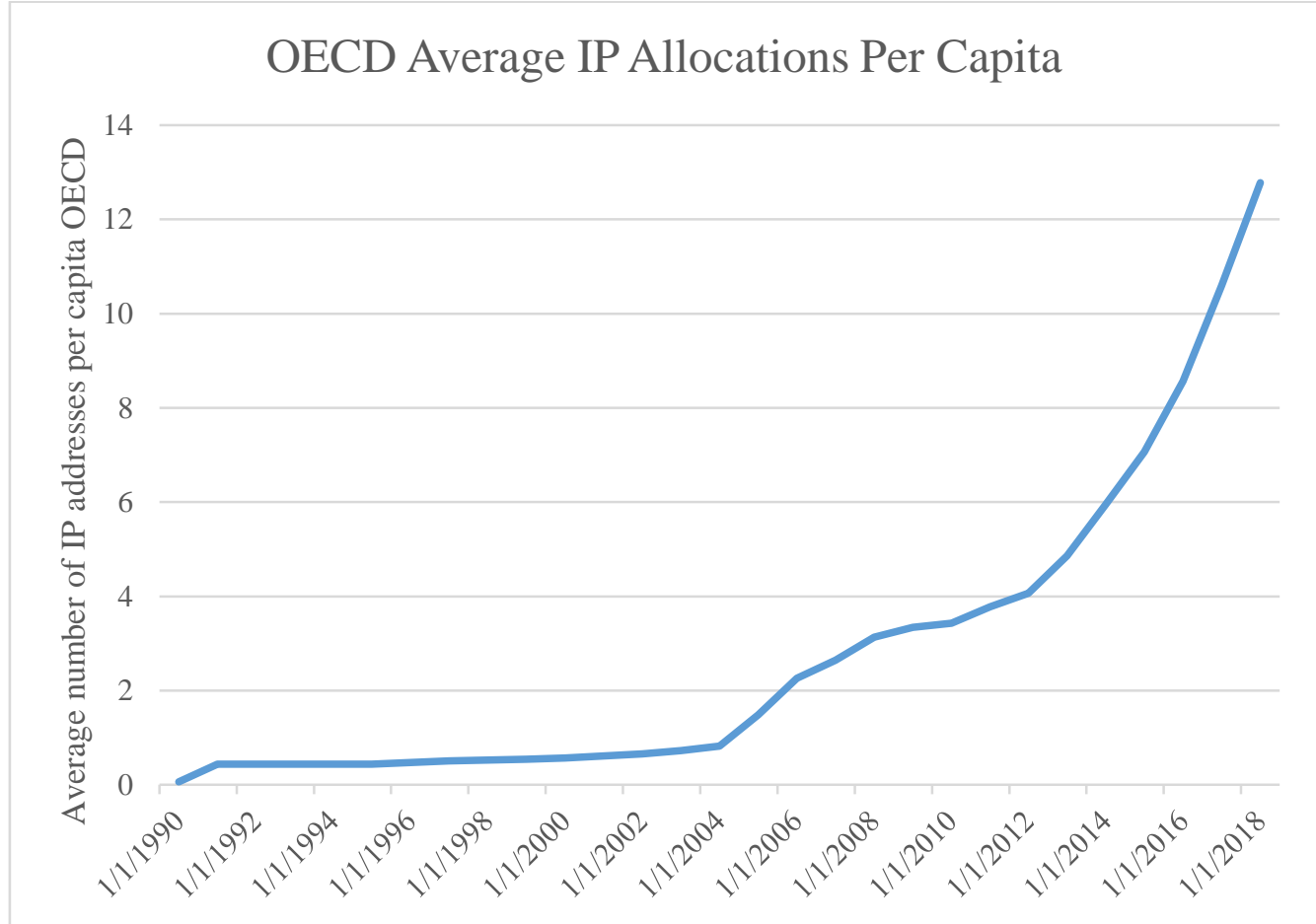

Source: Own representation based on data available from the APNIC.

Thus, the IP address allocation data allows for a good proxy of digitalization with advantages over other common proxies. Internet intensity/usage (e.g., percentage of the population) does not capture the true diffusion of digital technologies. A single person reporting having used the Internet could have access to the Internet at work, but not at home (or vice versa). The person could have a single desktop computer, which is a different circumstance from an individual with multiple connected devices (i.e., highly digitalized) each with a separate IP address. The same goes for the sheer number of connected devices in smart homes etc. Using IP data also avoids the problem - common to the most frequently used measures or indices of digitalization in the literature - of the addition or dropping of indicators with the emergence of new technologies or devices, i.e. a modern smartphone in 2017 is allocated an IP address in the same way as a desktop personal computer in 1995. However, there are also some caveats: Firstly, the allocation of IP addresses does not perfectly reflect actual usage. Secondly, in some circumstances a single IP address may, by way of a network address translator, be shared by a number of separate devices. Thirdly, where no allocation has been recorded, it does not definitively mean that no connected devices are being used in a particular jurisdiction. However, these caveats are not of sufficient concern to invalidate the usage of the data as a proxy (as also argued in Csonto et al. 2019).

Data on IPv4 and IPv6 allocations is provided by the Asia-Pacific Network Information Centre (APNIC) which has data for almost 200 countries and territories with data on IPv4 from 1990 and on IPv6 from 2009 - data is available on a monthly basis. While Csonto et al. (2019) use high frequency data (monthly) 
to construct an index of digitalization based on growth rates per country, for the purposes of the present study, we use annual data (i.e., the number of IP addresses as of 1 January (or closest available date) each year ${ }^{3}$ as the macroeconomic data is frequently only available on an annual basis.

\section{Data}

The dataset used in the present study is a panel of 36 members of OECD members (as of 2019) covering the period from 1995 to $2018^{4}$. An overview of the variables is provided in Table 1 (while a brief description of each variable and its source is available in the appendix - Table 4).

Table 1. Descriptive Statistics

\begin{tabular}{|l|c|c|c|c|c|}
\hline Variable & Obs & Mean & Std. Dev. & Min & Max \\
\hline TaxRev & 860 & 33.318 & 7.508 & 9.912 & 48.917 \\
\hline LnGDPpc & 862 & 10.269 & 0.676 & 8.545 & 11.615 \\
\hline TradeGDP & 862 & 90.293 & 53.311 & 16.679 & 408.362 \\
\hline AgriGDP & 847 & 2.749 & 2.058 & 0.214 & 16.855 \\
\hline IndustGDP & 847 & 25.633 & 5.338 & 10.517 & 41.107 \\
\hline GovtDebtGDP & 839 & 57.668 & 38.632 & 3.664 & 237.115 \\
\hline UrbanPop & 862 & 75.939 & 11.18 & 50.622 & 98.001 \\
\hline Unemployment & 862 & 7.805 & 4.142 & 1.805 & 27.466 \\
\hline inFDIGFCF & 855 & 0.22 & 0.444 & -1.647 & 4.313 \\
\hline Inflation & 862 & 3.707 & 7.741 & -4.478 & 89.113 \\
\hline PolRights & 862 & 1.194 & 0.581 & 1 & 5 \\
\hline CivLib & 862 & 1.447 & 0.769 & 1 & 6 \\
\hline BankingCrisis & 862 & 0.122 & 0.327 & 0 & 1 \\
\hline SovCrisis & 862 & 0.013 & 0.112 & 0 & 1 \\
\hline POPgrowth & 826 & 0.552 & 0.781 & -2.233 & 2.963 \\
\hline Digital & 858 & 3.295 & 5.574 & 0 & 50.145 \\
\hline
\end{tabular}

Source: Own representation.

The dataset is comprised of economic, institutional, specialization and social determinants of tax revenue, most of which are commonly used in the literature. In addition, our variable of interest is added, as are dummy variables to represent banking crises and sovereign debt crises.

$L n G D P p c$ is the natural log of GDP per capita (in 2010 international dollars) as a measure of the economic development of an economy (Gupta 2007). In the literature on the determinants of tax, this variable is expected to have a positive

\footnotetext{
${ }^{3}$ Unfortunately, there are some gaps in the data from APNIC, in particular missing data related to the United States and Canada for whom no data on the allocation of IPv4 is available from the period from September 2007 to July 2009. Thus, there is no observation for IPv4 and therefore of the variable Digitalization (which includes IPv4 data) for either of those countries for those two years, namely 2008 or 2009.

${ }^{4}$ After initial reviews of the data, two observations were dropped from the analysis. Firstly, the data for Iceland for the year 2016. Due to an exceptional item of tax revenue - "stability contributions" - related to banks and credit institutions which amounted to over $17 \%$ of 2015 GDP - resulting in a tax revenue to GDP rate of over 50\% in 2016, compared to $35 \%$ in 2015 , and $37 \%$ in 2017 (for more, see Baldursson et al. 2017). Also dropped was one observation for Luxembourg which preliminary tests showed high residuals and leverage making it a significant outlier in the data.
} 
sign, as economies grow they tend to become more formalized and thus easier to tax, rising GDP per capita also reflects an advantageous stage of the economic cycle which should, amongst others, generate more profits and income and thus higher taxes (Clausing 2007). However, many of the contributions which make this finding consider developing countries. In developed economies, where tax revenues as a share of income tend to already be relatively high (such as the OECD), and in crisis years, during which governments follow expansive fiscal policy to support economic growth and reduce the tax burden, the variable could also have a negative sign (see, e.g., Arnold et al. 2011, Bird et al. 2008).

TradeGDP is the sum of imports and exports of both goods and services as a percentage of GDP. This variable serves as a proxy of the openness of an economy and is expected to have an ambiguous effect on tax revenues (Angeles-Castro and Ramirez-Camarillo 2014). On the one hand, higher levels of trade are a sign of openness and competitiveness which should reflect a formal economy and a good opportunity to generate higher tax revenues (for example, directly via tariffs, and indirectly via overall economic growth). On the other hand, the sample of countries in the present study are characterized by high levels of openness, integration and low barriers to trade which should mean that, particularly the direct channel, should not result in significantly higher tax revenues.

AgriGDP is the share of agriculture, forestry and fishing value-added as a percentage of GDP. The share of agriculture in value-added is expected to be negatively related to tax revenues based on the literature, as the sector is difficult to tax - with a high share of self-employed individuals and small and medium enterprises and shadow economy effects (Gupta 2007).

Industry is the share of industry value-added as a percentage of GDP. This is expected to have a positive effect as it reflects a more formal, advanced sector of the economy which is easier to tax and which creates a larger tax base (Eltony 2002).

GovtDebtGDP is General Government Gross Debt as a percentage of GDP (Teera and Hudson 2004). On one hand, government debt could have a positive effect on tax revenue, as government seeks to increase tax revenues in order to service the costs of servicing increasing debt. On the other hand, government debt could also be used to finance public spending, and governments may wish to borrow to fund spending in a favorable interest rate environment rather than raise taxes in a period of expansive fiscal policy.

Urban Pop considers the percentage of the overall population living in urban settings. This is expected to have a positive effect on tax revenue. Firstly, a higher percentage of the population living in urban areas indicates a higher level of industry, a larger service sector and a lower share of agriculture (Gupta 2007). Secondly, a higher share of urban-dwellers reduces the costs for tax authorities to enforce tax compliance.

Inward FDI/GFCF relates to inward foreign direct investment (FDI) relative to gross fixed capital formation (GFCF). This variable could have a negative effect on tax revenues as higher inward GDI could reflect government approach of using tax policy and other fiscal incentives in order to attract FDI from investors abroad (Cassou 1997). On the other hand, higher levels of inward FDI could also be a sign 
of an economy which is competitive on global markets and of the confidence of investors in the stability, including the fiscal sustainability, of a country (Gugler and Brunner 2007).

Inflation can reduce tax revenues in real terms due to the time lag between the tax debt being incurred and the government actually collecting revenues (Gnangnon and Brun 2019). This phenomenon is known as the Olivera-Tanzi effect (see, e.g., Tanzi 1977).

Political Rights and Civil Liberties are expected to be positively related to tax revenues (Angeles-Castro and Ramirez-Camarillo 2014). In democratic states with high levels of civil liberty, taxpayers may be more likely to willingly cooperate with state authorities to contribute to public coffers and have a lower incentive to seek to avoid or evade taxes (Alm and Torgler 2006). Strong state protection of individual rights also extends to property rights etc. which are conducive to functioning markets. In this instance a positive relationship will be indicated by a negative sign of the correlation as lower marks for political rights and civil liberties indicate a better performance in those areas.

Population Growth is used here as a proxy variable for social development and is expected to be positively related to tax revenues. Many factors contribute to a growing population including low levels of infant mortality, higher life expectancy, a (relatively) stable birth rate and immigration. The above factors reflect an economy with a functioning and adequate social security system, health care system and a high standard of living, while a growing economy may attract inward migration (Bahl 2003, Gnangnon and Brun 2019).

Banking Crisis and Sovereign Debt Crisis are dummy variables which take the value of 1 for the years a particular country was experiencing either a banking crisis (e.g., for many of the OECD countries this covers the Global Financial Crisis of 2007/8-2012) or a sovereign debt crisis. As can be seen in Figure 2, average tax revenues in the OECD fell by almost 1.5 percentage points from $2007(33.6 \%)$ to 2009 (32.3\%) before rising from 2010 on. Therefore, the effect of these two dummy variables is ex ante ambiguous. Some countries responded to the crises by implementing austerity measures and raising taxes in order the stabilize public finances particularly in relation to rising interest rates and debt levels (Bozio et al. 2015) whereas banking crises are also associated with a decline in tax revenues (Rogoff and Reinhart 2008, Limberg 2020). To construct the dummy variables, information on the years individual countries experienced a crisis was taken from the data on systemic crises from Laeven and Valencia (2018) and the Systemic Banking Crises Database II of Laeven and Valencia (2020).

Digitalization is our primary variable of interest and as discussed previously is a measure of the number of IP addresses (IPv4 and IPv6) allocated per capita. This variable has been used in Csonto et al. (2019). On the one hand, digitalization should have a positive effect on tax revenue via the direct and indirect channels. On the other hand, a highly digitalized economy could see a negative relationship, as digitalization exacerbates the problems of tax base erosion and profit shifting. A correlation matrix for all variables is included in the appendix (Table 6). 


\section{Empirical Model}

The empirical model estimated is based on the literature, theoretical considerations and the hypothesis that digitalization is a relevant determinant of tax revenues. Thus, panel data analysis is deemed to be the most appropriate approach.

\section{$\underline{\text { Static Analysis }}$}

The following regression is estimated (with subscripts $i$ and $t$ representing each country and time period, respectively):

TaxRev $_{i t}=\beta_{0}+\beta_{1}\left(\right.$ LnGDPpc $\left._{i t}\right)+\beta_{2}\left(\right.$ AgriGDP $\left._{i t}\right)+\beta_{3}\left(\right.$ TradeGDP $\left._{i t}\right)+$ $\beta_{4}\left(\right.$ IndustGDP $\left._{i t}\right)+\beta_{5}\left(\right.$ GovtDebtGDP $\left._{i t}\right)+\beta_{6}\left(\right.$ UrbanPop $\left._{i t}\right)+\beta_{7}\left(\right.$ Unemployment $\left._{i t}\right)+$ $\beta_{8}\left(\right.$ inFDIGFCF $\left._{i t}\right)+\beta_{9}$ (Inflation $\left._{i t}\right)+\beta_{10}\left(\right.$ POPgrowth $\left._{i t}\right)+\beta_{11}\left(\right.$ PolRights $\left._{i t}\right)+$ $\beta_{12}\left(\right.$ CivLib $\left._{i t}\right)+\beta_{13}\left(\right.$ BankingCrisis $\left._{i t}\right)+\beta_{14}\left(\right.$ SovCrisis $\left._{i t}\right)+\beta_{15}\left(\right.$ Digital $\left._{i t}\right)+\eta_{i}+\delta_{t}+v_{i t}$

where $\eta_{i}$ are time invariant unobservable country-specific effects, $\delta_{t}$ are time effects and $v_{i t}$ the error term.

To determine the model specification, we begin with the standard pooled ordinary-least-squares method (POLS), followed by a fixed effects (FE) method using diagnostic tests, it is determined that the fixed effects model is preferable to the POLS and a random effects (RE) model using the standard F-test and Hausman test (Hausman 1978) test. Following further diagnostic tests, it was determined that time-fixed effects should be included in the model and that there is a presence of heteroscedasticity (modified Wald statistic), cross-sectional/temporal dependence (using Pesaran's test for cross-sectional independence (Pesaran 2004)) and serial correlation in the error term (Wooldridge test for autocorrelation). Therefore, the Pooled OLS and FE model are estimated with Driscoll and Kraay (1998) standard errors which account for and correct standard errors given these characteristics.

\section{Dynamic Analysis}

Extending the static analysis to a dynamic panel data analysis by including a lagged dependent variable on the right hand side is important for two reasons: Firstly, the inclusion of a lagged dependent variable in the model is required in order to examine the relationship between previous values of tax revenue as a percentage of GDP on current year values. In the literature, it has been found that prior tax revenues are a determinant of current revenues. Secondly, it is needed to test the possibility that an omitted lagged dependent variable is causing model misspecification and giving rise to autocorrelation. Thus, an extended General Method of Moments estimator is applied as proposed by Blundell and Bond (1998) which uses lagged differences of $Y_{i t}$ as instruments for equations in both levels and first differences, i.e., the system GMM estimation (or sys-GMM). To allow this dynamic panel data analysis, it was required to take a sub-sample, which was done on the basis of time. For this purpose, the sys-GMM was applied to the data for the years 2007 to 2018, the period in which the average allocation of IP addresses per capita, our variable of interest which acts as a proxy of digitalization, 
increased substantially across the OECD (see Figure 3). Reducing the time period analyzed is also necessary to avoid instrument proliferation and to ensure that the short $\mathrm{N}$, long $\mathrm{T}$ requirement is met. The sys-GMM estimator is based on the assumption that disturbances are not serially correlated, as otherwise the estimator would be inconsistent. Thus, tests of autocorrelation up to order 2 in the firstdifferenced residuals are required. The test of serial correlation in the firstdifferenced residuals is consistent with the maintained assumption of no serial correlation. The $\operatorname{AR}(2)$ test fails to reject the null hypothesis that the firstdifferenced residual error term is not second-order serially correlated, while the $\mathrm{AR}(1)$ test rejects the null (at 5 per cent level of significance). The results of the sys-GMM dynamic panel data are presented in Table 3.

\section{Results}

Two estimation methods are employed: pooled OLS and fixed effects (FE) in a static analysis. Both specifications include year dummies; standard errors are robust to arbitrary heteroscedasticity and serial correlation. The results of the chosen estimators (Pooled OLS with Driscoll-Kraay Standard Errors (model 1) and Fixed Effects with Driscoll-Kraay standard errors (DKSE) (model 2) presented in Table 2.

Table 2. Results of the Static Model

\begin{tabular}{|l|c|c|}
\hline & $(\mathbf{1})$ & $\mathbf{( 2 )}$ \\
\hline LnGDPpc & $\begin{array}{c}\text { Pooled OLS } \\
\text { DKSE }\end{array}$ & $\begin{array}{c}\text { Fixed Effects } \\
\text { DKSE }\end{array}$ \\
\hline & $7.422^{* * *}$ & $-5.525^{* * *}$ \\
\hline TradeGDP & $(0.389)$ & $(0.941)$ \\
\hline & $0.01^{* *}$ & -0.001 \\
\hline AgriGDP & $(0.004)$ & $(0.005)$ \\
\hline IndustGDP & 0.02 & $-0.903^{* * *}$ \\
\hline & $(0.162)$ & $(0.123)$ \\
\hline GovtDebtGDP & $-0.232^{* * *}$ & $-0.08^{*}$ \\
\hline & $(0.065)$ & $(0.042)$ \\
\hline UrbanPop & $-0.011^{* * *}$ & $0.032^{* * *}$ \\
\hline & $(0.004)$ & $(0.003)$ \\
\hline Unemployment & 0 & $0.081^{* * *}$ \\
\hline & $(0.02)$ & $(0.028)$ \\
\hline inFDIGFCF & $0.286^{* *}$ & $-0.134^{* * *}$ \\
\hline & $(0.122)$ & $(0.029)$ \\
\hline Inflation & -0.831 & -0.005 \\
\hline & $(1.007)$ & $(0.148)$ \\
\hline PolRights & $0.312^{* * *}$ & -0.015 \\
\hline & $(0.053)$ & $(0.019)$ \\
\hline CivLib & $-3.273^{* * *}$ & -0.047 \\
\hline & $(0.577)$ & $(0.306)$ \\
\hline
\end{tabular}




\begin{tabular}{|l|c|c|}
\hline POPgrowth & $-3.07^{* * * *}$ & $0.563^{* *}$ \\
\hline & $(0.398)$ & $(0.248)$ \\
\hline BankingCrisis & $-1.705^{* *}$ & $-0.452^{* *}$ \\
\hline & $(0.63)$ & $(0.162)$ \\
\hline SovCrisis & 1.17 & $1.91^{* * *}$ \\
\hline & $(0.917)$ & $(0.447)$ \\
\hline Digital & $-0.218^{* * *}$ & $-0.074^{* * *}$ \\
\hline & $(0.047)$ & $(0.011)$ \\
\hline Cons & 0 & $89.524 * * *$ \\
\hline & $(0)$ & $(11.581)$ \\
\hline Observations & 787 & 787 \\
\hline (Within) R squared & 0.4864 & 0.3475 \\
\hline Year Fixed Effect & Yes & Yes \\
\hline
\end{tabular}

Standard errors are in parentheses.

$* * * \mathrm{p}<0.01, * * \mathrm{p}<0.05, * \mathrm{p}<0.1$

Table 3. Sys-GMM Dynamic Panel Data Analysis 2007-2018

\begin{tabular}{|c|c|}
\hline TaxRev & Sys-GMM \\
\hline \multirow[t]{2}{*}{$\operatorname{TaxRev}_{\mathrm{t}-1}$} & $1.169 * * *$ \\
\hline & $(0.124)$ \\
\hline \multirow[t]{2}{*}{ LnGDPpc } & $-2.484 *$ \\
\hline & $(1.321)$ \\
\hline \multirow[t]{2}{*}{ TradeGDP } & -0.003 \\
\hline & $(0.004)$ \\
\hline \multirow[t]{2}{*}{ AgriGDP } & -0.139 \\
\hline & $(0.133)$ \\
\hline \multirow[t]{2}{*}{ IndustGDP } & -0.018 \\
\hline & $(0.046)$ \\
\hline \multirow[t]{2}{*}{ GovtDebtGDP } & 0.007 \\
\hline & $(0.005)$ \\
\hline \multirow[t]{2}{*}{ UrbanPop } & 0.012 \\
\hline & $(0.019)$ \\
\hline \multirow[t]{2}{*}{ Unemployment } & $-0.135^{*}$ \\
\hline & $(0.077)$ \\
\hline \multirow[t]{2}{*}{ inFDIGFCF } & 0.045 \\
\hline & $(0.164)$ \\
\hline \multirow[t]{2}{*}{ Inflation } & -0.049 \\
\hline & $(0.038)$ \\
\hline \multirow[t]{2}{*}{ PolRights } & 0.363 \\
\hline & $(0.416)$ \\
\hline \multirow[t]{2}{*}{ CivLib } & -0.227 \\
\hline & $(0.334)$ \\
\hline \multirow[t]{2}{*}{ POPgrowth } & 0.613 \\
\hline & $(0.389)$ \\
\hline \multirow[t]{2}{*}{ BankingCrisis } & 0.442 \\
\hline & $(0.236)$ \\
\hline \multirow[t]{2}{*}{ SovCrisis } & 0.449 \\
\hline & $(0.615)$ \\
\hline Digital & $0.059 *$ \\
\hline
\end{tabular}




\begin{tabular}{|l|c|}
\hline & $(0.031)$ \\
\hline Constant & $20.292^{*}$ \\
\hline & 11.651 \\
\hline Number of obs. & 786 \\
\hline Number of groups & 36 \\
\hline Number of instruments & 32 \\
\hline AR(1) & 0.000 \\
\hline AR(2) & 0.467 \\
\hline Hansen test & 0.545 \\
\hline
\end{tabular}

Standard errors are in parentheses.

$* * * \mathrm{p}<0.01, * * \mathrm{p}<0.05, * \mathrm{p}<0.1$

\section{Discussion}

In terms of the static analysis which examined the determinants of tax revenues for 36 OECD countries over the period from 1995 to 2018, the results are broadly in line with expectations. The coefficient for GDP per capita is negative and significant at the 1 per cent level. The share of value added contributed by agriculture is also negative and significant at the 1 per cent level, as is the unemployment level. The coefficients of the share of the urban population, the sovereign debt crisis and the level of government debt to GDP all have a positive sign and are all significant at the 1 per cent level, with population growth positive at the 5 per cent level. Meanwhile, the existence of a banking crisis is negatively related to tax revenues at the 5 per cent level. While this is in line with the theory (see Limberg 2020), caution is needed in interpreting the relationship as data on the digitalization proxy was unavailable for the United States and Canada for the years 2008 and 2009 which may have impacted the results.

While Gnangnon and Brun (2018) consider an "Internet gap" (i.e., the ratio of a country's internet usage intensity to the world average internet usage intensity) and tax capacity in a sample of 164 countries, their findings suggest that by reducing the Internet gap, countries can raise their public revenues with lowincome countries standing to benefit the most. Gnangnon and Brun (2019) examine the Internet on resource versus non-resource tax revenue for 99 countries, finding that a higher Internet usage intensity has a negative effect on resource revenue and a positive effect on non-resource revenue (again with the impact of the Internet being more significant for less developed countries). In the present study, the variable of primary interest, a broader proxy measure of digitalization, is negative and significant at the 1 per cent level in the static analysis. This indicates that digitalization may indeed have a negative effect on the ability of governments in relatively highly digitalized and high tax jurisdictions to raise taxes - providing some evidence in support of Tanzi's fiscal termite warning. Thus, digitalization may indeed be exerting downward pressure on revenues generated which may be a factor in explaining the role of policymakers in OECD countries pushing, via the OECD itself and the OECD/G20 framework, for a multilateral solution to the tax challenges of digitalization. 
Based on the dynamic analysis of the subsample of 2007-2018, most variables maintain the sign of their coefficient but lose significance. It can be noted that the lagged dependent variable is positive and significant at the 1 per cent level, showing prior year values of the overall tax burden are good determinants of current year values as expected according to the literature. However, in the dynamic analysis for the subsample of 2007-2018, the variable of interest, namely digitalization, is now positively related to tax revenues but only at the 10 per cent level, contrary to what could be expected in line with Tanzi's fiscal termite prognosis. This suggests that the rapidly increasing digitalization in more recent years (with the diffusion of mobile devices etc.) has in fact had a positive effect on tax revenues. Thus, the findings for digitalization across both the static and dynamic analyses here are ambiguous and must be interpreted with caution. However, the findings are interesting and may nevertheless be useful in the policy debate as they may temper overly positive or negative attitudes on digitalization and tax capacity.

One question that could be raised concerns the argument that macroeconomic data such as gross domestic product, and by extension tax revenues as a percentage of GDP, are increasingly being misstated due to, for example, zero priced digital services and the role of prosumers (Welfens and Perret 2014, Ahmad et al. 2017, Moulton 2018, Itkonen 2019, OECD 2020a). Even a minor restatement of GDP upwards to reflect the realities of the modern digitalized economy, could see tax revenues (expressed as a percentage of GDP) plateauing or even falling. A better denominator for expressing comparable tax revenues across countries may better facilitate using macroeconomic data to analyze the true effects of digitalization on tax revenues.

It may be hard for policymakers to maintain broad support for new digital taxes when tax revenues are already seen to be stable or rising, particularly when digital firms with market power can pass the burden of new taxes completely on to users. If digitalization does indeed pose a threat to tax bases, governments must ensure the best possible data is available to support this argument.

\section{Conclusions}

The present paper contributes to the literature by placing a specific focus on OECD countries and examining macroeconomic determinants of tax revenues in a departure from previous contributions to the literature. It is found that digitalization may indeed have a negative impact on developed and highly digital countries' tax revenues, possibly supporting the position of national governments in seeking to find a new multilateral solution to the tax challenges of digitalization. However, results should be interpreted with caution considering the effect found in the static and dynamic analyses.

The findings lend support to previous findings in the literature that a country with high GDP per capita, a low share of inward FDI in relation to gross fixed capital formation, a sizeable industrial sector relative to the agricultural sector, an urbanized and growing population and the protection of civil liberties and 
democratic institutions is more likely to be in a position to generate higher tax revenues. Meanwhile, high levels of unemployment and the existence of a banking crisis may have a negative effect on tax revenue generation.

While digitalization and its impact on tax revenues have been to the forefront of national and international discussions on public revenues in recent years, previous studies which have considered large samples of developed and developing countries have found that ICT (usually based on Internet intensity) is positively related to tax revenues - providing evidence against Tanzi's fiscal termite outlook and against the focus placed on digitalization and tax by policymakers, nationally, at an EU level and at the global level (OECD/G20). However, these results may be affected by the heterogeneity of these larger samples of developed and developing countries in terms of level of economic development, tax capacity and the extent of digitalization with the marginal gains for less developed countries possibly masking the effects for more developed and digitalized firms. Future research could consider to expand the sample of countries considered here, to include nonOECD countries which are highly digitalized.

\section{Acknowledgments}

My thanks to Geoff Huston, Chief Scientist at APNIC for providing data on IP allocations. My thanks for helpful comments and suggestions are also due to Prof. Dr. Paul Welfens, Dr. Kaan Celebi, and colleagues at the EIIW/University of Wuppertal. I am also indebted to the anonymous reviewers for their valuable comments and suggestions and for feedback received when the paper was presented at the $15^{\text {th }}$ Annual International Symposium on Economic Theory, Policy \& Application, 29-30 June \& 1-2 July 2020, Athens, Greece. Any errors are my own.

\section{References}

Ahmad N, Ribarsky J, Reinsdorf M (2017) Can potential mismeasurement of the digital economy explain the post-crisis slowdown in GDP and productivity growth? OECD Statistics Working Papers 2017/09. Paris: OECD Publishing.

Allen J (2017) Technology and inequality - Concentrated wealth in a digital world. London: Palgrave Macmillan.

Alm J, Torgler B (2006) Culture differences and tax morale in the United States and Europe. Journal of Economic Psychology 27(2): 224-246.

Angeles-Castro G, Ramirez-Camarillo DB (2014) Determinants of tax revenue in OECD countries over the period 2001-2011. Contaduria y Administracion 59(3): 35-59.

Argyropolou V (2019) Digital tax, making enterprises pay their "fair" share. TILEC Discussion Paper, DP2019-007. Tilburg, Germany: Tilburg University.

Arnold JM, Brys B, Heady C, Johansson A, Schwellnus C, Vartia L (2011) Tax policy for economic recovery and growth. The Economic Journal 121(Feb): 59-80.

Bahl R (2003) Reaching the hardest to tax: consequences and possibilities. Presented at the "Hard to Tax: An International Perspective" Conference, Andrew Young School of Policy Studies, Georgia State University, May 2003. 
Baldursson FM, Portes R, Thorlaksson EE (2017) Iceland's capital controls and the resolution of its problematic bank legacy. Working Paper. Retrieved from: http://dx. doi.org/10.2139/ssrn.2996631 [Accessed 15 October 2020]

Bauer M (2018) Digital companies and their fair share of taxes: myths and misconceptions. ECIPE Occasional Paper 03/2018.

Bauer M (2019) Corporate tax out of control: EU tax protectionism and the digital services tax. Working Paper. European Centre for International Political Economy (ECIPE) and European Policy Information Center.

Baunsgaard T, Keen M (2010) Tax revenue and (or?) trade liberalization. Journal of Public Economics 94(9): 563-577.

Bird RM, Martinez-Vazquez J, Torgler B (2008) Tax effort in developing countries and high income countries; the impact of corruption, voice and accountability. Economic Analysis and Policy 38(1): 55-71.

Blundell R, Bond S (1998) Initial conditions and moment restrictions in dynamic panel data models. Journal of Econometrics 87(1): 115-143.

Bozio A, Emmerson C, Peichl A, Tetlow G (2015) European public finances and the great recession: France, Germany, Ireland, Italy, Spain and the United Kingdom compared. Fiscal Studies 6(4): 405-430.

Bruce D, Fox WF (2000) E-commerce in the context of declining state sales tax bases. National Tax Journal 53(4): 1373-1390.

Camara N, Tuesta D (2017) DiGiX: the digitization index. Working Paper No. 17/03. BBVA Research, Banco Bilbao Vizcaya Argentaria SA.

Cassou S (1997) The link between tax rates and foreign direct investment. Applied Economics 29(10): 1295-1301.

Cho D (2015) An empirical analysis of smartphone diffusions in a global context. Journal of Contemporary Eastern Asia 14(1): 45-55.

Choi C (2003) Does the Internet stimulate inward foreign direct investment? Journal of Policy Modeling 25(4): 319-326.

Cockfield A (2006) The rise of the OECD as informal "world tax organization" through national responses to e-commerce tax challenges. Yale Journal of Law \& Technology 8(1): 136-187.

Collechia A, Schreyer P (2002) The contribution of information and communication technologies in economic growth in nine countries. OECD Economic Studies No. 34, pp. 153-171, Paris: OECD.

Collin P, Colin N (2013) Task force on taxation of the digital economy. Report commissioned by the French Ministry for the Economy and Finance and Ministry for Industrial Recovery.

Corkery, J, Forder J, Svantesson D, Mercuri E (2013) Taxes, the Internet and the digital economy. Revenue Law Journal 23(1): 1-13.

Corrocher N, Ordanini A (2002) Measuring the digital divide: a framework for the analysis of cross-country differences. Journal of Information Technology 17(1): 9-19.

Clausing K (2007) Corporate tax revenues in OECD countries. International Tax and Public Finance 14(2): 115-33.

Csonto B, Huang Y, Tovar CE (2019) Is digitalization driving domestic inflation? IMF Working Paper WP/19/271. Washington DC: International Monetary Fund.

Driscoll JC, Kraay A (1998) Consistent covariance matrix estimation with spatially dependent panel data. Review of Economics and Statistics 80(4): 549-560.

Eltony MN (2002) Determinants of tax efforts in Arab countries. Working Paper 207. Arab Planning Institute.

European Commission (2014) Commission expert group of taxation of the digital economy. Report of the Expert Group. Brussels: European Commission. 
European Commission (2017) Communication from the commission to the European parliament and the council, a fair and efficient tax system in the European Union for the digital single market. COM(2017) 547 final. Brussels: European Commission.

European Commission (2018) Time to establish a modern, fair and efficient taxation standard for the digital economy, communication from the commission to the european parliament and the council. $\operatorname{COM(2018)} 146$ final. Brussels: European Commission.

G8 (2013) Group of eight, Lough Erne declaration, 18 July 2013. Retrieved from: https:// assets.Publishing.service.gov.uk/government/uploads/system/uploads/attachment_dat a/file/207543/180613_LOUGH_ERNE_DECLARATION.pdf. [Accessed 3 January 2020]

G20 (2012) G20 Leaders declaration, Los Cabos summit, 19 June 2012. Retrieved from: http://www.g20.utoronto.ca/2012/2012-0619-loscabos.html. [Accessed 3 January 2020]

Gnangnon SK, Brun JF (2018) Impact of bridging the internet gap on public revenue mobilization. Information Economics and Policy 43(2): 23-33.

Gnangnon SK, Brun JF (2019) Internet and the structure of public revenue: resource revenue versus non-resource revenue. Journal of Economic Structures 8(1): 1-26.

Goolsbee A (2000) In a world without borders: the impact of taxes on internet commerce. Quarterly Journal of Economics 115(2): 561-576.

Gündüc S (2019) Diffusion of innovation in competitive markets - A study on the global smartphone diffusion. Acta Physica Polonica A 135(3): 485-494.

Gugler P, Brunner S (2007) FDI effects on national competitiveness: a cluster approach. International Advances in Economic Research 13(3): 268-284.

Gupta AS (2007) Determinants of tax revenue efforts in developing countries. IMF Working Paper WP/07/184. Washington DC: International Monetary Fund.

Hadzhieva E (2019) Impact of digitalisation on international tax matters - Challenges and remedies. Study commissioned by the Committee on Financial Crimes, Tax Evasion and Tax Avoidance of the European Parliament. Luxembourg: European Union.

Hausman J (1978) Specification tests in econometrics. Econometrica 46(6): 1251-1271.

IMF - International Monetary Fund (2018) Fiscal monitor: capitalizing on good times. Washington DC: International Monetary Fund.

ITU - International Telecommunications Union (2015) The impact of taxation on the digital economy. Discussion Paper presented at the $15^{\text {th }}$ Global Symposium for Regulators, Libreville, Gabon, from 9 to 11 June 2015.

Itkonen J (2019) The macroeconomic implications of measurement problems due to digitalization. BoF Economics Review. No. 1/2019, Helsinki: Bank of Finland.

Jaumotte F, Lall S, Papageorgiou C (2008) Rising income inequality: technology, or trade and financial globalization. IMF Working Paper WP/08/185. Washington DC: International Monetary Fund.

Jorgenson DW (2001) Information technology and the U.S. economy. American Economic Review 91(1): 1-33.

Karagöz K (2013) Determinants of tax revenue: does sectorial composition matter? Journal of Finance, Accounting and Management 4(2): 50-63.

Katz R, Koutroumpis P, Callorda FM (2014) Using a digitization index to measure the economic and social impact of digital agendas. Info 16(1): 32-44.

Köthenbürger M (2020) Taxation of digital platforms. EconPol Working Paper 41. Munich: Ifo Institute.

Kononova K (2015) Some aspects of ICT measurement: comparative analysis of e-indexes. In $7^{\text {th }}$ International Conference on Information and Communication Technology, Kavala, 938-945. 
Koyuncu C, Yilmaz R, Ünver M (2016) Does ICT penetration enhance tax revenue? Panel evidence. Anadolu University Journal of Social Sciences (Nov): Special Issue.

Laeven L, Valencia F (2018) Systemic banking crises revisited. IMF Working Paper WP/18/206. Washington DC: International Monetary Fund.

Laevan L, Valencia F (2020) Systemic banking crises database II. IMF Economic Review 68(2): 307-361.

Lee-Makiyama H, Verschelde B (2016) OECD BEPS: reconciling global trade, taxation principles and the digital economy. In F Boccia, R Leonardi (eds.), The Challenge of the Digital Economy. London: Palgrave Macmillan.

Limberg J (2020) Banking crises and the modern tax state. Socio-Economic Review 0(0): 1-26. Retrieved from: https://doi.org/10.1093/ser/mwz055 [Accessed 15 October 2020].

Meijers H (2014) Does the internet generate economic growth, international trade or both? International Economics and Economic Policy 11(1): 137-163.

Moulton B (2018) GDP and the digital economy: keeping up with the changes. Bureau of Economic Analysis.

Noh Y, Yoo K (2008) Internet, inequality and growth. Journal of Policy Modeling 30(6): $1005-1016$.

OECD - Organisation for Economic Co-operation and Development (2013a) Action plan on base erosion and profit shifting. Paris: OECD Publishing.

OECD - Organisation for Economic Co-operation and Development (2013b) Measuring the internet economy: a contribution to the research agenda. OECD Digital Economy Papers No. 226. Paris: OECD Publishing.

OECD - Organisation for Economic Co-operation and Development (2014) Addressing the tax challenges of the digital economy, action 1: 2014 deliverable. Paris: OECD Publishing.

OECD - Organisation for Economic Co-operation and Development (2015) Addressing the tax challenges of the digital economy, action 1: 2015 final report. Paris: OECD Publishing.

OECD - Organisation for Economic Co-operation and Development (2017) OECD digital economy outlook 2017. Paris: OECD Publishing.

OECD - Organisation for Economic Co-operation and Development (2018) Tax challenges arising from digitalisation - Interim report 2018: inclusive framework on $B E P S, O E C D / G 20$ base erosion and profit shifting project. Paris: OECD Publishing.

OECD - Organisation for Economic Co-operation and Development (2019a) Addressing the tax challenges of the digitalisation of the economy - Policy note, OECD/G2O base erosion and profit shifting project. Paris: OECD Publishing.

OECD - Organisation for Economic Co-operation and Development (2019b) Vectors of digital transformation. OECD Digital Economy Papers No. 273. Paris: OECD Publishing.

OECD - Organisation for Economic Co-operation and Development (2019c) Unpacking e-commerce-Business models, trends and policies, Paris: OECD Publishing.

OECD - Organisation for Economic Co-operation and Development (2020a) A roadmap towards a common framework for measuring the digital economy. Report of the G20 Digital Economy Taskforce. Paris: OECD Publishing.

OECD - Organisation for Economic Co-operation and Development (2020b) Reports on the pillar one and pillar two blueprints. Public Consultation Document. 12 October 12 December 2020. Paris: OECD Publishing.

Olbert M, Spengel C (2017) International taxation in the digital economy: challenge accepted? World Tax Journal 9(1): 3-46. 
Olbert M, Spengel C (2019) Taxation in the digital economy - Recent policy developments and the question of value creation. ZEW Discussion Paper No. 19-010. Mannheim: Leibniz-Zentrum für Europäische Wirtschaftsforschung (ZEW).

Oliner SD, Sichel DE (2000) The resurgence of growth in the late 1990s: is information technology the story? Journal of Economic Perspectives 14(4): 322.

Piancastelli M (2001) Measuring tax effort of developed and developing countries: crosscountry panel data analysis 1985-1995. Working Paper 818. Institute of Applied Economic Research.

Pesaran MH (2004) General diagnostic tests for cross section dependence in panels. Cambridge Working Papers in Economics, 0435. Cambridge, UK: University of Cambridge.

Richmond K, Triplett RE (2018) ICT and income inequality: a cross-national perspective. International Review of Applied Economics 32(2): 195-214.

Rogers E (2003) Diffusion of innovations. New York: Free Press.

Rogoff K, Reinhart C (2008) This Time is Different: A Panoramic View of Eight Centuries of Financial Crises. NBER Working Paper 13882, March 2008.

Salahuddin M, Alam K (2016) Information and communication technology, electricity consumption and economic growth in OECD countries: a panel data analysis. Electrical Power and Energy Systems 76(3): 185-193.

Sand-Zantman W (2018) Taxation in the Digital Economy. Working Paper for the Institut d'Economie Industrielle, May 2018.

Schoen W (2018) Ten questions about why and how to tax the digitalized economy. Bulletin for International Taxation 72(4/5): 278-292.

Stotsky J, Woldemariam A (1997) Tax effort in Sub-Saharan Africa. IMF Working Paper WP/97/107. Washington DC: International Monetary Fund.

Tanzi V (1977) Inflation, lags in collection and the real value of tax revenue. IMF Staff Papers 26. Washington DC: International Monetary Fund.

Tanzi V (1996) Globalization, tax competition and the future of tax systems. IMF Working Paper WP/96/141. Washington DC: International Monetary Fund.

Tanzi V (2000) Globalization, technological developments, and the work of fiscal termites. IMF Working Paper WP/00/181. Washington DC: International Monetary Fund.

Teera J, Hudson J (2004) Tax performance: a comparative study. Journal of International Development 16(6): 785-802.

Ting A, Gray S (2019) The rise of the digital economy: rethinking the taxation of multinational enterprises. Journal of International Business Studies 50(9): 16561667.

UN - United Nations (2017) The digitalized economy: selected issues of potential relevance to developing countries, committee of experts on international cooperation in tax matters. E/C 18/2017/6. UN.

UNCTAD - United Nations Conference on Trade and Development (2019) Global ecommerce sales surged to $\$ 29$ trillion. UNCTAD/PRESS/PR/2019/007, Geneva, Switzerland, 29 March 2019. UNCTAD.

Vemuri VK, Siddiqi S (2009) Impact of commercialization of the internet on international trade: a panel study using the extended gravity model. International Trade Journal 23(4): 458-484.

Verhoef PC, Broekhuizen T, Bart Y, Bhattacharya A, Qi Dong J, Fabian N et al. (2019) Digital transformation: a multidisciplinary reflection and research agenda. Journal of Business Research. [In press] Retrieved from: https://www.sciencedirect.com/scien ce/article/pii/S0148296319305478. [Accessed 15 October 2020] 
Welfens PJJ, Perret JK (2014) Information \& communication technology and true real gdp: economic analysis and findings for selected countries. International Economics and Economic Policy 11(1-2): 5-27.

Wyckoff A, Loux J (2019) Going digital: back to the future. OECD Observer. Retrieved from: https://bit.ly/2ICp4x5. [Accessed 15 October 2020].

Xing Z (2018) The impacts of Information and communication technology (ICT) and ecommerce on bilateral trade flows. International Economics and Economic Policy 15(3): 565-586.

Yi M, Choi C (2005) The effect of the internet on inflation: panel data evidence. Journal of Policy Modeling 27(7): 885-889. 
Vol. 7, No. 4 Hanrahan: Digitalization as a Determinant of Tax Revenues in OECD...

Appendix

Table 4. Definition and Source of Variable Used in the Analysis

\begin{tabular}{|c|c|c|}
\hline Variable & Definition & Source \\
\hline TaxRev $_{\text {it }}$ & $\begin{array}{l}\text { Tax revenue as a percentage of } \\
\text { Gross Domestic Product (GDP) }\end{array}$ & OECD \\
\hline $\operatorname{lnGDPpc} c_{\mathrm{it}}$ & $\begin{array}{l}\text { Log of GDP per capita of } \\
\text { country } i \text { in year } t \text { in } 2010 \\
\text { International Dollars }\end{array}$ & $\begin{array}{l}\text { World Bank/World Development } \\
\text { Indicators }\end{array}$ \\
\hline TradeGDP $_{\text {it }}$ & $\begin{array}{l}\text { Sum of exports and imports of } \\
\text { goods and services as \% of GDP }\end{array}$ & $\begin{array}{l}\text { World Bank/World Development } \\
\text { Indicators } \\
\end{array}$ \\
\hline AgriGDP $_{\text {it }}$ & $\begin{array}{l}\text { Agriculture, forestry and fishing } \\
\text { value-added as a \% of GDP }\end{array}$ & $\begin{array}{l}\text { World Bank/World Development } \\
\text { Indicators }\end{array}$ \\
\hline IndustGDP $_{\text {it }}$ & $\begin{array}{c}\text { Industry (including construction) } \\
\text { value-added as a percentage of } \\
\text { GDP }\end{array}$ & $\begin{array}{l}\text { World Bank/World Development } \\
\text { Indicators }\end{array}$ \\
\hline GovtDebtGDP $_{\text {it }}$ & $\begin{array}{c}\text { General government gross debt } \\
\text { as \% GDP }\end{array}$ & $\begin{array}{l}\text { World Bank/World Development } \\
\text { Indicators }\end{array}$ \\
\hline UrbanPop $_{\text {it }}$ & $\begin{array}{c}\text { Urban population as \% of total } \\
\text { population }\end{array}$ & $\begin{array}{l}\text { World Bank/World Development } \\
\text { Indicators }\end{array}$ \\
\hline inFDIGFCF & $\begin{array}{l}\text { Inward FDI as a } \% \text { of Gross } \\
\text { Fixed Capital Formation }\end{array}$ & $\begin{array}{l}\text { Own calculation using data from } \\
\text { World Bank/World Development } \\
\text { Indicators }\end{array}$ \\
\hline Unemployment $_{\text {it }}$ & $\begin{array}{l}\text { Unemployment, total (as \% of } \\
\text { total labor force) }\end{array}$ & $\begin{array}{l}\text { World Bank/World Development } \\
\text { Indicators }\end{array}$ \\
\hline Inflation $_{\text {it }}$ & $\begin{array}{l}\text { Annual consumer price inflation } \\
\text { in percent }\end{array}$ & $\begin{array}{l}\text { World Bank/World Development } \\
\text { Indicators }\end{array}$ \\
\hline PolRights $_{\text {it }}$ & Political rights & Freedom House (2020) \\
\hline CivLib $_{\text {it }}$ & Civil liberties & Freedom House (2020) \\
\hline POPgrowth $_{\text {it }}$ & $\begin{array}{l}\text { Growth rate of the total } \\
\text { population in percent }\end{array}$ & $\begin{array}{l}\text { Own calculation using data from } \\
\text { World Bank/World Development } \\
\text { Indicators }\end{array}$ \\
\hline Banking Crisis & $\begin{array}{c}\text { Dummy variable on annual basis } \\
\text { if respective country experienced } \\
\text { a banking crisis. Crises over } 5 \\
\text { years are truncated at } 5 \\
\end{array}$ & $\begin{array}{l}\text { Laeven and Valencia } \\
\quad(2018,2020)\end{array}$ \\
\hline SovCrisis & $\begin{array}{l}\text { Dummy variable which takes the } \\
\text { value of } 1 \text { in years when a } \\
\text { country is experiencing a } \\
\text { sovereign debt crisis. Crises over } \\
5 \text { years are truncated at } 5\end{array}$ & $\begin{array}{l}\text { Laeven and Valencia } \\
\qquad(2018,2020)\end{array}$ \\
\hline Digital & $\begin{array}{l}\text { Digital penetration/intensity - } \\
\text { allocation of IP addresses per } \\
\text { capita }\end{array}$ & $\begin{array}{l}\text { Own calculation based on data } \\
\text { provided by APNIC }\end{array}$ \\
\hline
\end{tabular}

Source: Own representation. 
Table 5. IP Allocations per Capita 2018

\begin{tabular}{|l|c|}
\hline Country & IP Allocations Per Capita 2018 \\
\hline Iceland & 50.1452426 \\
\hline Sweden & 41.3802219 \\
\hline Luxembourg & 34.0464056 \\
\hline Netherlands & 26.314549 \\
\hline Australia & 25.4440285 \\
\hline Norway & 24.9034517 \\
\hline Switzerland & 21.3199972 \\
\hline United Kingdom & 19.6373991 \\
\hline Germany & 15.3133055 \\
\hline Denmark & 14.7342418 \\
\hline Estonia & 14.1491191 \\
\hline United States & 13.8604189 \\
\hline France & 13.1182164 \\
\hline Finland & 12.5364134 \\
\hline Ireland & 12.4845324 \\
\hline Czechia & 11.3123851 \\
\hline Austria & 11.0702509 \\
\hline Slovenia & 10.3860394 \\
\hline Italy & 9.17202016 \\
\hline Korea & 8.8472736 \\
\hline Belgium & 8.78872828 \\
\hline Poland & 7.75557301 \\
\hline Latvia & 7.06380967 \\
\hline Japan & 6.63836143 \\
\hline Spain & 6.22539814 \\
\hline Lithuania & 5.57558953 \\
\hline Slovakia & 5.46876682 \\
\hline New Zealand & 4.43992795 \\
\hline Israel & 3.89469461 \\
\hline Canada & 3.10869289 \\
\hline Hungary & 3.02623417 \\
\hline Portugal & 2.82440967 \\
\hline Greece & 2.13103752 \\
\hline Turkey & 1.4729257 \\
\hline Chile & 0.427825706 \\
\hline Mexico & \\
\hline Soure: & \\
\hline
\end{tabular}

Source: Own representation and calculations based on APNIC data. 
Table 6. Correlation Matrix

\begin{tabular}{|c|c|c|c|c|c|c|c|c|c|c|c|c|c|c|c|c|}
\hline Variables & TaxRev & $\begin{array}{c}\text { Ln } \\
\text { GDPpc }\end{array}$ & $\begin{array}{l}\text { Trade } \\
\text { GDP }\end{array}$ & $\begin{array}{l}\text { Agri } \\
\text { GDP }\end{array}$ & $\begin{array}{l}\text { Indust } \\
\text { GDP }\end{array}$ & $\begin{array}{c}\text { Govt Debt } \\
\text { GDP }\end{array}$ & $\begin{array}{c}\text { Urban } \\
\text { Pop }\end{array}$ & $\begin{array}{l}\text { Unemp- } \\
\text { loyment }\end{array}$ & $\begin{array}{l}\text { inFDI } \\
\text { GFCF }\end{array}$ & $\begin{array}{c}\text { Infla- } \\
\text { tion }\end{array}$ & $\begin{array}{c}\text { Pol } \\
\text { Rights }\end{array}$ & $\begin{array}{l}\text { Civ } \\
\mathrm{Lib}\end{array}$ & $\begin{array}{c}\text { POP } \\
\text { growth }\end{array}$ & $\begin{array}{c}\text { Banking } \\
\text { Crisis }\end{array}$ & $\begin{array}{c}\text { Sov } \\
\text { Crisis }\end{array}$ & Digital \\
\hline TaxRev & 1.000 & & & & & & & & & & & & & & & \\
\hline LnGDPpc & 0.465 & 1.000 & & & & & & & & & & & & & & \\
\hline TradeGDP & 0.189 & 0.149 & 1.000 & & & & & & & & & & & & & \\
\hline AgriGDP & -0.316 & -0.586 & -0.237 & 1.000 & & & & & & & & & & & & \\
\hline IndustGDP & -0.356 & -0.350 & -0.179 & 0.123 & 1.000 & & & & & & & & & & & \\
\hline GovtDebtGDP & 0.164 & 0.217 & -0.261 & -0.223 & -0.254 & 1.000 & & & & & & & & & & \\
\hline UrbanPop & 0.092 & 0.432 & -0.102 & -0.126 & -0.288 & 0.114 & 1.000 & & & & & & & & & \\
\hline Unemployment & 0.061 & -0.400 & -0.050 & 0.175 & -0.151 & 0.190 & -0.253 & 1.000 & & & & & & & & \\
\hline inFDIGFCF & 0.067 & 0.159 & 0.459 & -0.150 & -0.160 & -0.074 & 0.100 & -0.046 & 1.000 & & & & & & & \\
\hline Inflation & -0.243 & -0.408 & -0.098 & 0.618 & 0.157 & -0.173 & -0.185 & 0.041 & -0.053 & 1.000 & & & & & & \\
\hline PolRights & -0.471 & -0.477 & -0.148 & 0.523 & 0.201 & -0.088 & -0.098 & 0.047 & -0.101 & 0.621 & 1.000 & & & & & \\
\hline CivLib & -0.399 & -0.540 & -0.229 & 0.481 & 0.173 & 0.033 & -0.101 & 0.157 & -0.134 & 0.559 & 0.739 & 1.000 & & & & \\
\hline POPgrowth & -0.166 & 0.368 & -0.018 & -0.017 & -0.048 & -0.162 & 0.407 & -0.390 & 0.085 & 0.100 & 0.155 & 0.099 & 1.000 & & & \\
\hline BankingCrisis & -0.005 & -0.002 & 0.072 & -0.054 & -0.125 & 0.108 & -0.062 & 0.127 & 0.082 & 0.090 & 0.010 & -0.009 & -0.065 & 1.000 & & \\
\hline SovCrisis & 0.034 & -0.046 & 0.030 & 0.010 & -0.053 & 0.168 & -0.001 & 0.218 & -0.026 & -0.050 & 0.069 & 0.015 & -0.115 & -0.011 & 1.000 & \\
\hline Digital & 0.098 & 0.398 & 0.079 & -0.270 & -0.154 & 0.030 & 0.239 & -0.242 & -0.077 & -0.151 & -0.146 & -0.242 & 0.205 & -0.099 & -0.010 & 1.000 \\
\hline
\end{tabular}

Source: Own calculations. 